\title{
Motivational Encouragement of Self Performance Assessment Instrument in Mastering National Language Based on Keller's Arcs Model
}

\section{Arul Das Arumugam \& Vijayaletchumy Subramaniam}

To Link this Article: http://dx.doi.org/10.6007/IJARBSS/v12-i1/12339

DOI:10.6007/IJARBSS/v12-i1/12339

Received: 05 November 2021, Revised: 07 December 2021, Accepted: 30 December 2021

Published Online: 16 January 2022

In-Text Citation: (Arumugam \& Subramaniam, 2022)

To Cite this Article: Arumugam, A. Das, \& Subramaniam, V. (2022). Motivational Encouragement of Self Performance Assessment Instrument in Mastering National Language Based on Keller's Arcs Model. International Journal of Academic Research in Business and Social Sciences, 12(1), 2673-2689.

Copyright: (c) 2022 The Author(s)

Published by Human Resource Management Academic Research Society (www.hrmars.com) This article is published under the Creative Commons Attribution (CC BY 4.0) license. Anyone may reproduce, distribute, translate and create derivative works of this article (for both commercial and non0-commercial purposes), subject to full attribution to the original publication and authors. The full terms of this license may be seen at: http://creativecommons.org/licences/by/4.0/legalcode

Vol. 12, No. 1, 2022, Pg. $2673-2689$

Full Terms \& Conditions of access and use can be found at http://hrmars.com/index.php/pages/detail/publication-ethics 


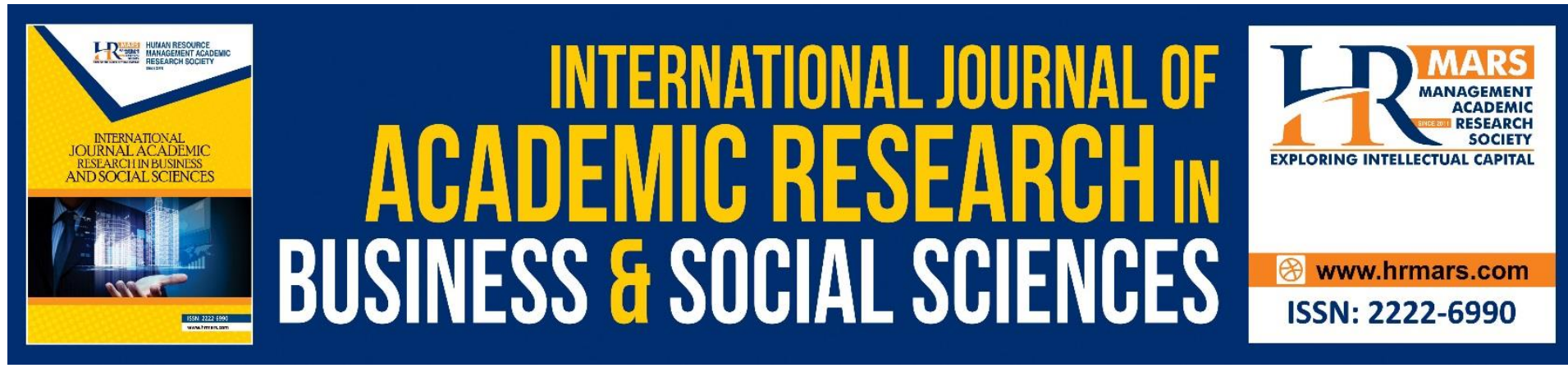

\title{
Motivational Encouragement of Self Performance Assessment Instrument in Mastering National Language Based on Keller's Arcs Model
}

\author{
Arul Das Arumugam \& Vijayaletchumy Subramaniam \\ Department of Malay Language Faculty of Modern Languages and Communication, \\ University Putra Malaysia
}

\begin{abstract}
This research aims to identify the influences of using Self Performance Assessment Instrument which known in Malay language as Instrumen Penilaian Prestasi Kendiri (IPKK) on motivational encouragement for students' learning in national language of Malaysia. Before conducting this survey, the students had a chance to use IPKK for two different tests. The survey uses the Attention (A) - Relevance (R) - Confidence (C) - Satisfaction (S) Model of Motivation, or ARCS, which was pioneered by John M. Keller. This research is quantitativebased and uses questionnaires as the main instrument. Approximately 115 students from three different schools, specifically National Type Tamil Schools or Sekolah Jenis Kebangsaan Tamil were chosen as purposive sample. They compared every item based on their experience, which is to say after and before using IPPK. The findings indicate that IPPK influenced the students' motivational encouragement to control balancing emotions when mastering the national language. It piques their attention or desire to learn, supply appropriate knowledge, form self-confidence, and generate self-satisfaction.
\end{abstract}

Keywords: Instrument, Motivation, Attention, Relevance, Confidence, Satisfaction

\section{Introduction}

The Self Performance Assessment Instrument or Instrumen Penilaian Prestasi Kendiri (IPKK), is a material resulting from studies on teachers' actions by adapting John Elliot Keller's model (1999). It is specially produced for the Malay Language subject and focuses on the comprehension paper. It contain constructs as per clones of the language system (grammar and comprehension), question number according to section, marks according to section, total marks, correct construct, and achievement construct (must be filled in according to the colour determinant table, which are green - strong, yellow - moderate, and red - weak).

\section{Problem Statement}

Stress breakdown or emotional disturbances happens often among students, at times resulting in a desire to commit suicide (Metro Daily, 30.4.2019; Utusan Borneo, 28.10.2016). According to Mahmud (2012), a majority of students experience stress as they do not achieve the scores desired by their parents and teachers. These emotional disturbances influence the 
students' interest towards learning Malay Language in school. These results disinterest towards the Malay Language reading materials factor into influencing their level of mastery (Peng, 2016). There are students who fail in learning this second language even though they give priority to this language. Students whom have basics in learning Malay Language may feel that the subject is easy when compared to students whom face difficulty. Therefore, a student's attitude in learning a second language is found to influence the process of learning the language (Pormalu et al., 2017). Cook (1991) defined second language as a language that is learned by an individual in addition to their mother tongue. Razin and Subramaniam(2019) identified five problems in learning Malay Language as a second language, namely a disinterest in learning Malay Language as a second language, a low mastery of Malay Language vocabulary, linguistic differences between their first language (Tamil) interferes with learning Malay Language as a second language, insufficient familial support in learning Malay Language, and a lack of merging of Malay Language as the student's family communication tool. Findings from the 2018 Yearly Postmortem Report by the Daily School Management Division of Ministry of Education, Malaysia stated that active learning from students was still at a low level when compared to other aspects. For a large number of students, Malay Language is easy to learn but hard to master (Nathesan, 2012). Environmental factors such as the provision of infrastructure facilities and quality learning materials also play a vital role in academic achievement (Bakar and Haridas, 2015). Therefore, there is a need for the creation of IPPK as the emotional disturbances experienced by the students in National Type Tamil schools in mastering Malay Language which is the national language of Malaysia. As the official language, passing Malay Language at the Malaysian Certificate of Education(MCE) or Sijil Pelajaran Malaysia (SPM) level is a main necessity for someone who wishes to pursue a career in the government sector in Malaysia (General Circular Letter No. 1 of 2006: Measures to Strengthen the Use of the National Language in the Public Service). This also rings true for several private sectors such as banking, industrial factories, and farming. With that, the confidence in using Malay Language is becoming a major requirement these days.

Intellectual achievement in examinations have a strong influence towards the emotional balance of a student (Ismail, 2020). Other than that, determining the brightness or bleakness of a person's future is typically determined in what they achieve during their examinations (Sawal, 2020). Low-achieving students would feel aggrieved and this would influence their motivational drive to learn and appreciate Malay Language in the years to come. Students whom have basics in Malay Language find that Malay Language is an easy subject, if compared to students whom face difficulties when learning this language. Therefore, intrinsic motivation formed from force is less effective if it is not accompanied by interest and confidence in themselves. A number of students experience depression when they do not obtain satisfactory marks in the Malay Language paper. This depression then leads to a fear of them to speak Malay. Some of these students face difficulties in understanding grammar as well as vocabulary. This situation is shaped by the student's intrinsic motivation which is the force behind the process of rise, sustain, and control interest and self-confidence (Pormalu et al., 2017). Therefore, the objective of this research is to clarify the influence of IPPK towards the students' motivational drive to master Malay Language in National Type Tamil Schools known as Sekolah Jenis Kebangsaan Tamil(SJKT) in the district of Hulu Langat, Selangor, Malaysia. 


\section{Literature Review}

Pormalu et al (2017) surveyed the attitudes of 87 students on learning Malay Language as a second language at SJKT Bukit Mertajam from a cognitive, affective, and conative aspect. The findings showed that a change in attitude towards learning Malay Language influences a rise in UPSR results in the year 2013. From a cognitive aspect, some of the students agreed that they were able to improve themselves after giving attention towards their learning of learning Malay Language and this was hoped to help them further their studies to a higher level with the help of the government. From an affective aspect, students were positive towards Malay Language as it was interesting and easy to learn. Conatively, students stated that persistent effort produced an improvement in performance no matter if it was average or low, and increased their language skills. This research has continuity with current studies as it involves students at SJKT whom are not native Malay speakers.

Razin \& Subramaniam (2019) identified the types of mistakes in prefixes and suffixes among 50 Indian Primary 5 students in SJKT Serdang. Through written tests regarding prefixes and suffixes based on Corder's Error Analysis Theory, researchers found that students did not fully master prefixes and suffixes. Husaini and Salleh (2017), on the other hand, studied the Malay grammar errors when learning Malay Language as a second language. The researchers identified the types of sentence structure errors, analysed the sentence structure errors in learning a second language, and elaborated on the steps to overcome grammatical mistakes in learning a second language. The findings also found that there were unclear sentence structures, grammatically incorrect usage of verbs, errors in affixes, and spelling errors. This research has continuity with current studies as it involves students in SKJT.

Ooi \& Subramaniam(2016) analysed the level of motivation among students whom learned Malay Language as a second language among 77 Chinese students in upper primary whom failed their Malay Language papers in a National Type Chinese School known as Sekolah Jenis Kebangsaan Cina(SJKC) $14^{\text {th }}$ Miles, Hulu Langat, Selangor. The researchers adapted Halliday's Theory of Interaction and used questionnaires that contained five items. For the first item, 58 (75.3\%) of the students admitted to not doing extra Malay Language practices other than their Malay Language school homework. This stunted their ability to think and apply language knowledge received during schooltime. For the second item, 74 (96\%) of students stated that they did not speak Malay Language as there were no environmental factors that allowed them to learn through experience. The third item showed that $67(87 \%)$ students stated they were disinterested in Malay Language as the forming of words and sentence structures were difficult to learn in addition to the factor of having Malay Language teachers whom are not Chinese. Chinese students found that teachers whom are not of their own race would not explain in Chinese when they were not able to understand the second language. However, for the fourth item, only 29 (38\%) students felt that Malay Language was not important. This group of students assumed that this second language was not beneficial as most of their subjects were taught in their mother tongue rather than Malay Language or English. This notion did not exist among the other 48 (62\%) of students whom understood that it was important to be mastered. This group of students assumed as such as there were two factors which are exemption from transition class if they passed the Malay Language paper during the UPSR examinations, and the role of language as the medium of communication to others. This research has continuity with current researches as it involves motivation of students in SKJC whom are not native Malay speakers.

Ismail \& Zakaria (2019) identified factors that shape Chinese students' motivation towards learning Malay Language and analysed the most dominant factor between intrinsic 
and extrinsic motivations based on the Chinese students studied, which are 30 out of 76 students in upper primary in SJKC Chung Hwa, Teluk Kemang. The questionnaires were used as instruments were modified from questionnaire tests towards learning languages by (Gardner, 2005). There were six questions and the findings differed from one another. For question one, eight students admitted to always be thinking about Malay Language lessons learned in school while two other students thought about it occasionally while the remaining 22 students never thought about it at all. For question two, 18 students stated they would like to learn language via mass media / online while the 23 other students wished to learn at tuition centres or language academies. Question three saw 25 students state that they referred to the teacher immediately when facing problems when learning Malay Language, two asked for help during examinations, and five students did not seek help. As for question four, 11 students admitted that their parents or guardian would constantly help them complete their Malay Language homework, 10 students were barely given any attention, and 14 other students indicated that their parents provided reference materials. Question five saw six students stated that they enjoyed befriending friends who learned Malay Language diligently, and 28 students admitted that they have had previous help from friends to learn Malay Language. All of them were interested to learn. For question six, 10 students were interested in learning Malay Language as there were a variety of learning materials, six students enjoyed it as they were given rewards, and 23 students were interested in Malay Language as there were various activities. As a whole, the most dominant factor that influenced a student's motivation to learn Malay Language were extrinsic factors which are peers whom are diligent in learning Malay Language and were often made into their references for help. This research has continuity with current research as it involves students' motivation in SJKC whom are not native speakers of Malay Language.

Mahmudah (2016) found that 28 students in the $11^{\text {th }}$ class for the academic year of 2015/2016 in MA NU Salafiyah Demak Negeri Walingso, Semarang, Indonesia had positive perception towards using the ARCS Model in speaking, reading, and writing classes. The researcher used qualitative methods by employing the observation method during English lessons in the classroom, student's English worksheets, student's workbooks, and pictures. Observation in the classroom focused on the students' activities and the teacher's teaching strategies based on the ARCS Model (Attention, Relevance, Confidence, Satisfaction) in English. A closed questionnaire which contained 15 question items on the students' perception towards the usage of ARCS Model to teach English was used. The interview instrument was used on the teacher teaching the XI class as weall as on several students. The teacher was questioned on general ideas on the strategies in using the ARCS Model. Based on observation, the researcher observed the four elements of ARCS, namely A-Attention, RRelevance, C-Confidence, S-Satisfaction. Referring to the element 'Attention', the teacher motivated the student with a) the speaking learning method to explain theory materials and relaxed method to pull the students' interests, and b) prioritizing the students' feelings in determining interesting materials. Referring to the element 'Relevance', the teacher used suitable materials and informed of the expected learning competencies. As for the element 'Confidence', the teacher would always unearth the students' confidence to accept reading materials even though at times the materials were of a higher level of difficulty. The teacher unearthed the confidence by encouraging the students to put hopes on success and to arrange the learning process from easy to difficult. Students who were under the category of slow learners were always encouraged to not give up, and in fact with the hopes to succeed, the students were motivated to engage in active learning. For the element 'Satisfaction', the 
researcher found that the students were satisfied when the teachers praised them, gave them chances to show off their special skills for students whom have reached certain capabilities and gave chances to students to assist their peers. This research has continuity with current studies as it involves the ARCS Model with learning English as a second language.

Reynolds, Roberts, Lindsay, Hauk and Janet (2017) found that the ARCS Model of Motivation was useful in increasing learning involvement during teaching and learning information literacy. This reseach identified the ways three librarians in different institutions using Keller's ARCS Model of Motivation in information literacy teaching processes. All three librarians practiced self-reflection and used various evaluation techniques to evaluate and improve teaching practices. This research has continuity with current researches as it involves the ARCS Model.

\section{Methodology}

This research utilized the quantitative research design, namely observation. This observation research was to study the perception of the respondents on the motivational encouragement from IPPK. Therefore, this research was adapted from the ARCS Model of Motivation as pioneered by John M. Keller, an American psychologist. This model is a method that arouses motivation within a student towards learning and achievement. Therefore, every strategy is arranged according to priority. The acronym ARCS is made up of four English words, which are A-Attention, R-Relevance, C-Confidence, S-Satisfaction. Keller categorised strategies for each of the four components with auxiliary verbs which are to acquire attention, provide relevance, form confidence, and generate satisfaction. Respondents are required respond based on their experience by using IPPK for diagnostic tests and March monthly tests. Therefore, experienced students performed three steps which are to circle the number which corresponds with the full score in the Question Number space, to write the total score in Construct B (Correct) and scratch on the precise colours of the traffic light in Construct C (Achievement). This sampling research is a purposive sampling whereby a group of Primary 4 students from a SJKT school whom are learning Malay Language as their second language. Other than that, only students who do not have a truancy problem were accepted as a participant or respondent for this research. With that, the research respondents were separated according to sample, whereby Sample 1 comprised of 50 students, Sample 2 comprised of 60 students, and Sample 3 comprised of 5 students whereby all the samples were students of three SJKTs' in Mukim Semenyih, Hulu Langat District, Selangor. The research instrument contains 12 items adapted from the ARCS Model of Motivation.

Every ARCS component, which are A-Attention, R-Relevance, C-Confidence, SSatisfaction, contains three items in accordance to the strategies as presented by John M. Keller, where in each component there are strategies to acquire A-Attention which is A1 Rise of Perception; A2, Rise of Investigation; and A3, Variables on ways to retain students' attention. Therefore, the items in component $A$ are: $A 1$ - IPPK is what piqued by interest to ascertain achievement in every clone of the language system; A2 - IPPK stimulates my interest in identifying the strengths and weaknesses in the Malay Language comprehension paper; and A3 - IPPK made me realise that I needed to be careful in a weak language system clone. This strategy provided R-Compatibility which comprises of: R1: Goal Orientation; R2: Motive Match; and R3: Familiarity. Therefore, the items formed from are R1-IPPK is suitable with my level of understanding and age, and R2- IPPK provided me with options to arrange for my next step, and R3-Instruction and user guide of IPPK is clear and simple. The strategy to form CConfidence stands from C1: The need for learning which is the students' style is to be assisted 
to build positive hope for success; C2: Chance for success which is through supportive learning experience or to increase the student's trust towards their own abilities; and C3: Personal control which is the way students clearly comprehend that their success is based on their own efforts and ability. Therefore, the items as ascertained are C1 - IPPK allowed me to determine the next target; C2 - IPPK supports motivation that I may move forward; and C3 - IPPK helped me to understand the real success. The last strategy is to generate $S$ - Satisfaction which comprises of: S1: Natural causes; S2: Positive causes; S3: Equity. Therefore, the items determined are S1 - I am able to use IPPK to measure the rate of future success; S2 - IPPK sparks off my motive to move forward in the direction of excellence; and S3 - IPPK triggers my positive self-worth (by doing practices and so forth). All these items have gone through validation and trustworthiness when the researcher conducted research at a degree level.

The respondents were required to mark / at the agreement scale that is thought of suitable in the POST segment, once experienced in using IPPK. Afterwards, the respondents will fill in the pre-segment which is before experiencing using IPPK. There are three scales of agreement, namely Agree, Disagree, and Unsure.

\section{Findings and Discussion}

The response of every respondent is seen from two perspectives, which are the segment of prior to having experience (PRE) and the segment after having experience (POST) using IPPK. The phrase 'prior to having experience' refers to the experience of seeing the instrument for the first time. The phrase 'after having experience' refers to the experience in the involvement in using the instrument twice. Therefore, every item is evaluated in these two perspectives.

Table 1.0 : Findings for Element A - Attention

\begin{tabular}{|c|c|c|c|c|c|c|c|c|}
\hline \multirow{2}{*}{$\begin{array}{l}\text { ARCS } \\
\text { CODE }\end{array}$} & \multirow[t]{2}{*}{ ITEM } & \multirow{2}{*}{$\begin{array}{c}\text { SAMPL } \\
\text { E }\end{array}$} & \multicolumn{3}{|c|}{ PRA } & \multicolumn{3}{|c|}{ POST } \\
\hline & & & AGREE & $\begin{array}{c}\text { DIS- } \\
\text { AGREE }\end{array}$ & $\begin{array}{l}\text { UN- } \\
\text { SURE }\end{array}$ & AGREE & $\begin{array}{c}\text { DIS- } \\
\text { AGREE }\end{array}$ & $\begin{array}{l}\text { UN- } \\
\text { SURE }\end{array}$ \\
\hline \multirow[t]{3}{*}{ A1 } & \multirow{3}{*}{$\begin{array}{l}\text { IPPK is } \\
\text { what } \\
\text { piqued by } \\
\text { interest to } \\
\text { ascertain } \\
\text { achieveme } \\
\text { nt in every } \\
\text { clone of the } \\
\text { language } \\
\text { system. }\end{array}$} & A & 0 & $\begin{array}{c}50 \\
(100 \%)\end{array}$ & 0 & $\begin{array}{c}50 \\
(100 \%)\end{array}$ & 0 & 0 \\
\hline & & B & 0 & $\begin{array}{c}60 \\
(100 \%)\end{array}$ & 0 & $\begin{array}{c}60 \\
(100 \%)\end{array}$ & 0 & 0 \\
\hline & & C & 0 & $\begin{array}{c}5 \\
(100 \%)\end{array}$ & 0 & $\begin{array}{c}5 \\
(100 \%)\end{array}$ & 0 & 0 \\
\hline \multirow[t]{3}{*}{$A 2$} & \multirow{3}{*}{$\begin{array}{l}\text { IPPK } \\
\text { stimulates } \\
\text { my interest } \\
\text { in } \\
\text { identifying } \\
\text { the } \\
\text { strengths } \\
\text { and } \\
\text { weaknesses }\end{array}$} & A & 0 & $\begin{array}{c}50 \\
(100 \%) \\
\end{array}$ & 0 & $\begin{array}{l}50 \\
(100 \%) \\
\end{array}$ & 0 & 0 \\
\hline & & B & 0 & $\begin{array}{c}60 \\
(100 \%)\end{array}$ & 0 & $\begin{array}{c}60(100 \\
\%)\end{array}$ & 0 & 0 \\
\hline & & $\mathrm{C}$ & 0 & $\begin{array}{c}5 \\
(100 \%)\end{array}$ & 0 & $\begin{array}{c}5(100 \% \\
)\end{array}$ & 0 & 0 \\
\hline
\end{tabular}




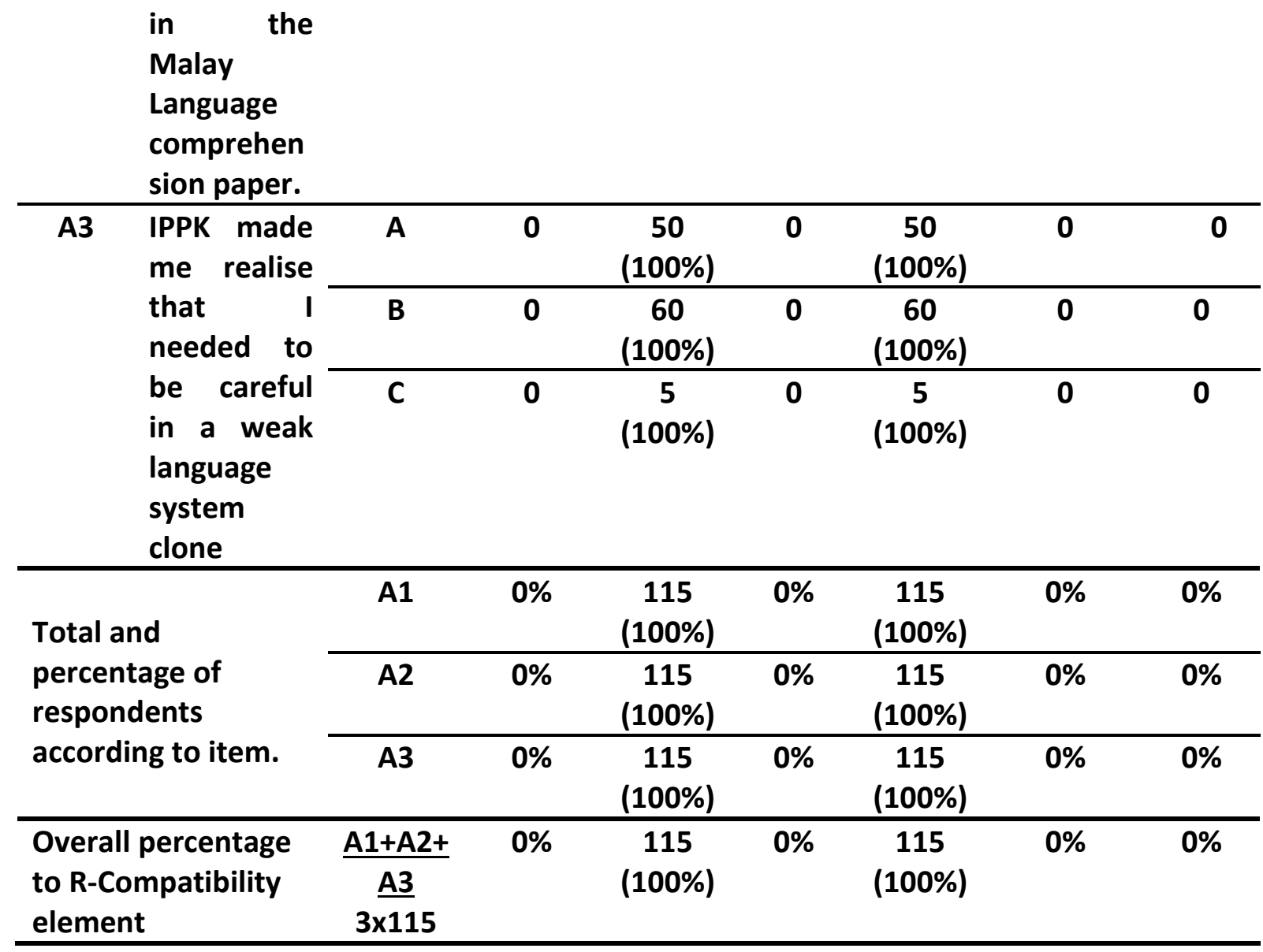

Based on Table 1.0, the general findings for the Attention element show that choosing Agree was dominant $100 \%$ in the Post segment when compared to $0 \%$ or the pre-segment. In fact, all the respondents chose Disagree in the pre-segment. The same findings were $100 \%$ for items 1, 2 and 3 whereby all respondents chose Agree in the Post segment and chose Disagree in the pre-segment. This shows that all the respondents had a positive perception for the post segment that the IPPK piqued their interest to understand achievement in every language system clone (item 1), to stimulate to identify the strengths and weaknesses in Malay Language comprehension paper (item 2), and realise the need to be careful in weak language system clones (item 3 ). This differs from the findings of the pre-segment whereby $100 \%$ of the respondents disagreed at the beginning as they were not aware of the true function of the self-assessment instrument.

Referring to item A1, all 115 respondents gave their own responses for both Pre and Post segment of using IPPK. For the Pre-segment, no respondents from all three samples agreed or were unsure that IPPK was able to pique their interest in knowing the achievements in every language system clone. $100 \%$ of the respondents disagreed with item $A 1$. This meant that not one of the respondents had a positive perception on the ability of the instrument to give rise to their interest in identifying true achievements. However, after experiencing it, all $115(100 \%)$ of respondents from all three samples agreed that the IPPK model aroused interest to perceive achievement in every language system clone. This finding shows that IPPK succeeded in triggering positive perception in students towards trust and self-confidence.

Referring to item A2, all 115 respondents responded in the Pre and Post segment. For the pre-segment, all 115 respondents (100\%) had a passive perception, whereby they disagreed that the model had the ability to stimulate them to identify the strengths and 
weaknesses in the Malay Language comprehension paper. However, this perception changed once they used IPPK twice. All 50 (100\%) respondents from Sample A, 60 (100\%) respondents from Sample B, and 5 (100\%) respondents from Sample $C$ agreed that IPPK helped them feel stimulated to identify the strengths and weaknesses in the Malay Language comprehension paper. This showed that a rise in investigation has existed among the respondents.

As for item A3, all 115 respondents gave responses for both Pre and Post segments for IPPK usage. For the pre-segment, 50 respondents (100\%) from Sample A, 60 respondents (100\%) from Sample B, and 5 respondents (100\%) from Sample C were not aware that IPPK may make them realise to be careful in weak language cloning systems. However, in the Post usage segment, all $100 \%$ of respondents agreed that the IPPK model made them aware to be careful in weak language system clones. This response showed that students are able to retain attention towards learning.

As a while, the findings for all three items shows positive development. IPPK succeeded in triggering curiosity on development of the position in every language system clone. Therefore, students used the inquiry or investigation method on themselves. This drives the students' motivation to retain attention, especially towards weak language system clones. This is in line with the Keller's strategies to command for attention, where he suggested that the experience of learning to be interesting and is be able to stimulate the students. The Attention category encompasses human attributes such as orientation reflection, curiosity, and seeking sensation. Therefore, Keller suggested A1: Rise in perception, A2: Rise in investigation, and A3: Variables on retaining student attention. Through the element of observation, IPPK was able to create interest and stimulate curiosity to understand the next development among students.

Table 2.0 : Findings for Element $\mathrm{R}$ - Relevance

\begin{tabular}{|c|c|c|c|c|c|c|c|c|}
\hline \multirow{2}{*}{$\begin{array}{l}\text { ARCS } \\
\text { CODE }\end{array}$} & \multirow[t]{2}{*}{ ITEM } & \multirow[t]{2}{*}{ SAMPLE } & \multicolumn{3}{|c|}{ PRE } & \multicolumn{3}{|c|}{ POST } \\
\hline & & & AGREE & $\begin{array}{l}\text { DIS- } \\
\text { AGREE }\end{array}$ & $\begin{array}{l}\text { UN- } \\
\text { SURE }\end{array}$ & AGREE & $\begin{array}{l}\text { DIS- } \\
\text { AGREE }\end{array}$ & $\begin{array}{l}\text { UN- } \\
\text { SURE }\end{array}$ \\
\hline \multirow[t]{3}{*}{ R1 } & \multirow{3}{*}{$\begin{array}{l}\text { IPPK is } \\
\text { suitable } \\
\text { with my } \\
\text { level of } \\
\text { understan } \\
\text { ding and } \\
\text { age }\end{array}$} & $A$ & 0 & $\begin{array}{c}2 \\
(4 \%)\end{array}$ & $\begin{array}{c}48 \\
(96 \%)\end{array}$ & $\begin{array}{c}50 \\
(100 \%)\end{array}$ & 0 & 0 \\
\hline & & B & 0 & 0 & $\begin{array}{c}60 \\
(100 \%)\end{array}$ & $\begin{array}{c}60 \\
(100 \%)\end{array}$ & 0 & 0 \\
\hline & & C & 0 & $\begin{array}{c}2 \\
(40 \%)\end{array}$ & $\begin{array}{c}3 \\
(60 \%)\end{array}$ & $\begin{array}{c}5- \\
(100 \%)\end{array}$ & 0 & 0 \\
\hline \multirow[t]{3}{*}{$\mathbf{R 2}$} & \multirow{3}{*}{$\begin{array}{l}\text { IPPK } \\
\text { provided } \\
\text { me with } \\
\text { options to } \\
\text { arrange for } \\
\text { my next } \\
\text { step. }\end{array}$} & A & 0 & $\begin{array}{c}2 \\
(4 \%)\end{array}$ & $\begin{array}{c}48 \\
(96 \%)\end{array}$ & $\begin{array}{c}50 \\
(100 \%)\end{array}$ & 0 & 0 \\
\hline & & B & 0 & 0 & $\begin{array}{c}60 \\
(100 \%)\end{array}$ & $\begin{array}{c}60 \\
(100 \%)\end{array}$ & 0 & 0 \\
\hline & & C & 0 & $2(40 \%)$ & $3(60 \%)$ & $\begin{array}{c}5 \\
(100 \%)\end{array}$ & 0 & 0 \\
\hline \multirow[t]{4}{*}{ R3 } & Instruction & A & 0 & $1(2 \%)$ & 49 & 50 & 0 & 0 \\
\hline & and user & & & & $(98 \%)$ & $(100 \%)$ & & \\
\hline & $\begin{array}{l}\text { guide of } \\
\text { IPPK is }\end{array}$ & B & 0 & 0 & $\begin{array}{c}60 \\
(100 \%) \\
\end{array}$ & $\begin{array}{c}60 \\
(100 \%)\end{array}$ & 0 & 0 \\
\hline & clear and & C & 0 & 0 & 5 & 5 & 0 & 0 \\
\hline
\end{tabular}




\begin{tabular}{|c|c|c|c|c|c|c|c|}
\hline simple & & & & $(100 \%)$ & (100\%) & & \\
\hline \multirow{3}{*}{$\begin{array}{l}\text { Total and } \\
\text { percentage of } \\
\text { respondents } \\
\text { according to item }\end{array}$} & R1 & $0(0 \%)$ & $\begin{array}{c}4 \\
(3.48 \%)\end{array}$ & $\begin{array}{c}111 \\
(96.52 \\
\%)\end{array}$ & $\begin{array}{c}115 \\
(100 \%)\end{array}$ & $0(0 \%)$ & $0(0 \%)$ \\
\hline & R2 & $0(0 \%)$ & $\begin{array}{c}4(3.48 \\
\%)\end{array}$ & $\begin{array}{c}111 \\
(96.52 \\
\%) \\
\end{array}$ & $\begin{array}{c}115 \\
(100 \%)\end{array}$ & $0(0 \%)$ & $0(0 \%)$ \\
\hline & R3 & $0(0 \%)$ & $\begin{array}{c}1(0.87 \\
\%)\end{array}$ & $\begin{array}{c}114 \\
(99.13 \\
\%) \\
\end{array}$ & $\begin{array}{c}115 \\
(100 \%)\end{array}$ & $0(0 \%)$ & $0(0 \%)$ \\
\hline $\begin{array}{l}\text { Overall percentage } \\
\text { to R-Compatibility } \\
\text { element }\end{array}$ & $\frac{R 1+R 2+R}{3 \times \frac{3}{115}}$ & $0 \%$ & $2.6 \%$ & $97.4 \%$ & $100 \%$ & $0 \%$ & $0 \%$ \\
\hline
\end{tabular}

Findings show that all 115 respondents responded for both Pre and Post IPPK usage. In general, the overall percentage of the Compatibility element in the Post segment clearly sides $100 \%$ to the choosing of Agree. However, in the pre-segment, the findings are mixed between Disagree (2.6\%) and Unsure (97.4\%). None of the respondents responded with Agree (0\%). Referring to the total and percentage of respondents according to item, the Post segment for R1, R2, and R3, $100 \%$ of respondents chose Agree while none (0\%) of respondents chose Disagree and Unsure. However, the difference can be seen in the pre-segment whereby R1, Agree (0\%), Disagree (3.48\%), and Unsure (96.52\%).

When studied separately according to sample, the findings for items R1, R2, and R3 may be expressed in detail. Referring to item 1, all 115 (100\%) of respondents from all three samples in the Post segment agree that the IPPK model is suitable with their level of comprehension and their age. This differs from the perception in the pre-segment where four respondents disagreed and the remaining 111 stated they were unsure. Not one had an early perception that IPPK was suitable with their comprehension level. The findings for R1 showed that IPPK may help pique motivation to fully understand the students' needs based on their abilities. Students were able to circle the question number that obtained the full marks, tabulate the full mark scores, and find the position of the colour in the Colour Determinant Table.

Referring to item R2 in the Post segment, all 115 (100\%) of respondents agreed that the IPPK model provided them choices to arrange their next steps. This means that the steps to identify the real achievements in every language system clone stimulates the students to improve upon their achievements in future examinations by determining their next moves. In the pre-segment, two respondents each in Sample $A$ and $C$ disagreed that IPPK provided them with a choice to organise their next step. Approximately 48 respondents in Sample A, all 60 respondents in Sample B, and 3 respondents in Sample C chose unsure. Overall, the match between the motive for learning with the learning steps can be seen in the Post segment.

Next, for R1 which is 'Instruction and Guidance in using the IPPK Model is clear and simple, all 115 (100\%) of respondents in all three samples agreed in the Post segment, even though no one agreed to do so in the pre-segment. In the pre-segment, one respondent from Sample A disagreed, while the other 49 were unsure. The response from Sample B and Sample C were $100 \%$ entirely focused on the 'Unsure' option. This shows that there exists a closeness among the clarity of the guide for using IPPK and its user-friendly nature. 
Overall, the response in the Post segment for all three items shows that students are able to interact with the IPPK are in line with Keller's suggestions to prompt students' needs according to ability. Other than that, IPPK takes into account different learning environments for every student, therefore students are free to learn whether individually or in groups. Referring to the closeness aspect, the internal motivation for the respondents can be dug up as there are new knowledge in IPPK which may assist in achieving the set goals. The aspect of influencing positive attitude by fulfilling a need or the student's personal goals is the definition given by Keller as a strategy to provide suitability.

Table 3.0: Findings for Element $\mathrm{C}$ - Confidence

\begin{tabular}{|c|c|c|c|c|c|c|c|c|}
\hline \multirow{2}{*}{$\begin{array}{l}\text { ARCS } \\
\text { CODE }\end{array}$} & \multirow[t]{2}{*}{ ITEM } & \multirow[t]{2}{*}{ SAMPLE } & \multicolumn{3}{|c|}{ PRE } & \multicolumn{3}{|c|}{ POST } \\
\hline & & & AGREE & $\begin{array}{c}\text { DIS- } \\
\text { AGREE }\end{array}$ & $\begin{array}{l}\text { UN- } \\
\text { SURE }\end{array}$ & AGREE & $\begin{array}{c}\text { DIS- } \\
\text { AGREE }\end{array}$ & $\begin{array}{l}\text { UN- } \\
\text { SURE }\end{array}$ \\
\hline \multirow[t]{3}{*}{ C1 } & \multirow{3}{*}{$\begin{array}{l}\text { IPPK } \\
\text { helps me } \\
\text { to set my } \\
\text { next } \\
\text { target }\end{array}$} & A & 0 & $\begin{array}{c}2 \\
(4 \%)\end{array}$ & $\begin{array}{c}48 \\
(96 \%)\end{array}$ & $\begin{array}{c}50 \\
(100 \%)\end{array}$ & 0 & 0 \\
\hline & & B & 0 & 0 & $\begin{array}{c}60 \\
(100 \%)\end{array}$ & $\begin{array}{c}60 \\
(100 \%)\end{array}$ & 0 & 0 \\
\hline & & C & 0 & 0 & $\begin{array}{c}5 \\
(100 \%)\end{array}$ & $\begin{array}{c}5 \\
(100 \%)\end{array}$ & 0 & 0 \\
\hline \multirow[t]{3}{*}{ C2 } & \multirow{3}{*}{$\begin{array}{l}\text { IPPK } \\
\text { supports } \\
\text { motivati } \\
\text { on that I } \\
\text { am able } \\
\text { to } \\
\text { succeed }\end{array}$} & A & 0 & 0 & $\begin{array}{c}50 \\
(100 \%)\end{array}$ & $\begin{array}{c}50 \\
(100 \%)\end{array}$ & 0 & 0 \\
\hline & & B & 0 & 0 & $\begin{array}{c}60 \\
(100 \%)\end{array}$ & $\begin{array}{c}60 \\
(100 \%)\end{array}$ & 0 & 0 \\
\hline & & C & 0 & $\begin{array}{c}1 \\
(20 \%)\end{array}$ & $\begin{array}{c}4 \\
(80 \%)\end{array}$ & $\begin{array}{c}5 \\
(100 \%)\end{array}$ & 0 & 0 \\
\hline \multirow[t]{3}{*}{ C3 } & \multirow{3}{*}{$\begin{array}{l}\text { helps me } \\
\text { to know } \\
\text { my true } \\
\text { success. }\end{array}$} & A & 0 & $\begin{array}{c}1 \\
(2 \%)\end{array}$ & $\begin{array}{c}49 \\
(98 \%)\end{array}$ & $\begin{array}{c}50 \\
(100 \%)\end{array}$ & 0 & 0 \\
\hline & & B & 0 & 0 & $\begin{array}{c}60 \\
(100 \%) \\
\end{array}$ & $\begin{array}{c}60 \\
(100 \%) \\
\end{array}$ & 0 & 0 \\
\hline & & C & 0 & $\begin{array}{c}2 \\
(40 \%)\end{array}$ & $\begin{array}{c}3 \\
(60 \%)\end{array}$ & $\begin{array}{c}5 \\
(100 \%)\end{array}$ & 0 & 0 \\
\hline \multirow{3}{*}{\multicolumn{2}{|c|}{$\begin{array}{l}\text { Total and } \\
\text { percentage of } \\
\text { respondents } \\
\text { according to item }\end{array}$}} & C1 & 0 & $\begin{array}{c}2 \\
(1.8 \%)\end{array}$ & $\begin{array}{c}113 \\
(98.2 \%)\end{array}$ & $\begin{array}{c}115 \\
(100 \%)\end{array}$ & 0 & 0 \\
\hline & & C2 & 0 & $\begin{array}{c}1 \\
(0.9 \%)\end{array}$ & $\begin{array}{c}114 \\
(99.1 \%)\end{array}$ & $\begin{array}{c}115 \\
(100 \%)\end{array}$ & 0 & 0 \\
\hline & & C3 & 0 & $\begin{array}{c}3 \\
(2.6 \%) \\
\end{array}$ & $\begin{array}{c}112 \\
(97.4 \%)\end{array}$ & $\begin{array}{c}115 \\
(100 \%)\end{array}$ & 0 & 0 \\
\hline \multicolumn{2}{|c|}{$\begin{array}{l}\text { Overall } \\
\text { percentage to C - } \\
\text { Compatibility } \\
\text { element }\end{array}$} & $\frac{C 1+C 2+C}{\underline{3} 3 \times 115}$ & 0 & $1.74 \%$ & $98.26 \%$ & $100 \%$ & 0 & 0 \\
\hline
\end{tabular}

The findings showed that all 115 respondents provided a response for both the Pre and Post segment of IPPK usage. In general, the overall percentage for the Compatibility element in the Post segment clearly favours $100 \%$ of Agree. However, in the pre-segment, it 
was found that it was a mixture of Disagree (1.74\%) and Unsure (98.26\%). Not one respondent chose Agree (0\%). Referring to the total percentage of respondents according to item, the Post segment for C1, C2, and C3, 100\% of respondents chose Agree while non (0\%) chose Disagree and Unsure. However, the difference can be seen in the pre-segment, whereby for C1, Agree (0\%), Disagree (1.8\%), and Unsure (98.2\%). For item C2 in the pre-segment, Agree (0\%), Disagree $(0.9 \%)$, and Unsure $(99.1 \%)$. For item C3 in the pre-segment, Agree $(0 \%)$, Disagree (2.6\%), and Unsure (97.4\%).

When studied separately according to sample, the findings for items in C1, C2, and C3 are able to be explained in detail. According to item C1, all 115 respondents gave each other their responses for both the Pre and Post segment for IPPK usage. For the Post segment, all $115(100 \%)$ of respondents from all three samples agree that the model helped themselves to determine their next target. Therefore, the findings for Disagree and Unsure for the Post segment were all at $0 \%$. This shows positive development when compared to the pre-segment as none of the respondents $(0 \%)$ agreed by having early perception that IPPK would help them determine their next target. Two respondents from Sample A chose Disagree while the other 48 respondents chose Unsure. This showed that IPPK encourages students to determine their next target based on current achievements. This means that IPPK is able to inject learning needs which is to build positive hope to succeed.

For item C2, all 115 respondents gave responses for both the Pre and Post segment. Referring to the Post segment, all 115 (100\%) of respondents agreed that the IPPK model supports their motivation to succeed. Therefore, the findings of Disagree and Unsure in the Post segment stand at $0 \%$. This indicates positive development as compared to the presegment where $0 \%$ of the respondents whom had early perception that IPPK would be able to support their motivation to succeed. One of the respondents from Sample 3 chose Disagree, while the remaining four respondents chose Unsure together with all the respondents from Sample A totally 50 people and 60 people from Sample B. This finding shows that IPPK is able to inject motivation into the souls of the students to succeed in mastering the national language. This will indirectly increase the chances for success through learning experiences that support or increase the student's belief in their on capabilities.

Just as items C1 and C2, all 115 respondents responded in the Pre and Post segment for C3. Referring to the Post segment, all 115 (100\%) of respondents from all three samples agreed that the IPPK model helped them to know true success for the Malay Language comprehension paper. Therefore, the findings for Disagree and Unsure in the Post segment stands at $0 \%$. This showcases positive development when compared to the pre-segment where none of the respondents $(0 \%)$ has early perceptions that IPPK would be able to help them know real success in the Malay Language comprehension paper. One respondent from Sample $A$ and two respondents from Sample $C$ chose Disagree, while 49 respondents from Sample $A$ and 3 respondents from Sample $C$ chose Unsure. All 60 respondents from Sample B chose unsure. The findings from the Post segment found it to be more positive when compared to the findings in the pre-segment. These findings encourage the students' personal control over intimating clearly that their success is based on their own efforts and capabilities.

As a whole, Keller's question on the sowing of confidence though self-learning is answered in the Post segment items C1, C2, and C3. Referring to C1, there are a number of students who possess a high level of ability to identify the evaluation criteria. Students were also able to identify the learning objectives so that they make their own self-evaluations at the end of a learning session. With regards to C2: Chances of success, IPPK possess logical 
criteria, which is the determining of traffic light colours, namely green - may progress more, yellow - see and alert, and red - stop and revise. This logic influences the students' confidence in creating hope and determining more meaningful steps. Referring to C3: Self-control, IPPK created stable learning environment, therefore allowing students to regulate their own selfcontrol. In line with Keller's opinions, IPPK provides correction responses to students and helps them so discern the source of the mistake and to make a corrective action. Therefore, Keller's definition on the strategies to form confidence by fulfilling the student's needs or personal goals as an effort to influence positive attitude can be identified. Among the support strategies proposed by Keller is to build positive hope for success, increase the student's belief in their own abilities, and to create self-control whereby the student themselves would clearly discern that their success depends on their own efforts and abilities.

Table 4.0 : Findings for element S - Satisfaction

\begin{tabular}{|c|c|c|c|c|c|c|c|c|}
\hline \multirow{2}{*}{$\begin{array}{l}\text { ARCS } \\
\text { CODE }\end{array}$} & \multirow[t]{2}{*}{ ITEM } & \multirow[t]{2}{*}{ SAMPLE } & \multicolumn{3}{|c|}{ PRE } & \multicolumn{3}{|c|}{ POST } \\
\hline & & & AGREE & $\begin{array}{c}\text { DIS- } \\
\text { AGREE } \\
\end{array}$ & $\begin{array}{l}\text { UN- } \\
\text { SURE }\end{array}$ & AGREE & $\begin{array}{c}\text { DIS- } \\
\text { AGREE }\end{array}$ & $\begin{array}{l}\text { UN- } \\
\text { SURE }\end{array}$ \\
\hline \multirow[t]{4}{*}{ S1 } & \multirow{4}{*}{$\begin{array}{l}\text { I can use } \\
\text { IPPK to } \\
\text { measure } \\
\text { my future } \\
\text { success. }\end{array}$} & A & 0 & $3 \quad(6 \%)$ & 47 & $50(100 \%)$ & 0 & 0 \\
\hline & & B & & & $(94 \%)$ & & & \\
\hline & & C & 0 & 0 & $\begin{array}{c}60 \\
(100 \%)\end{array}$ & $60(100 \%)$ & 0 & 0 \\
\hline & & & 0 & $1(20 \%)$ & $4(80 \%)$ & $5(100 \%)$ & 0 & 0 \\
\hline \multirow[t]{3}{*}{ S2 } & \multirow{3}{*}{$\begin{array}{l}\text { IPPK } \\
\text { stimulates } \\
\text { my motive } \\
\text { to move } \\
\text { forward } \\
\text { towards } \\
\text { success. }\end{array}$} & A & 0 & $2(4 \%)$ & $\begin{array}{c}48 \\
(96 \%) \\
\end{array}$ & $50(100 \%)$ & 0 & 0 \\
\hline & & B & 0 & 0 & $\begin{array}{c}60 \\
(100 \%)\end{array}$ & $60(100 \%)$ & 0 & 0 \\
\hline & & C & 0 & $2(40 \%)$ & $3(60 \%)$ & $5(100 \%)$ & 0 & 0 \\
\hline \multirow[t]{3}{*}{ S3 } & \multirow{3}{*}{$\begin{array}{l}\text { IPPK } \\
\text { triggers } \\
\text { positive } \\
\text { self-worth } \\
\text { (doing } \\
\text { practices } \\
\text { and such) } \\
\end{array}$} & A & $\begin{array}{c}31 \\
(62 \%)\end{array}$ & 7 (14\%) & $\begin{array}{c}12 \\
(24 \%)\end{array}$ & $50(100 \%)$ & 0 & 0 \\
\hline & & B & $\begin{array}{c}25 \\
(42 \%)\end{array}$ & 0 & $\begin{array}{c}35 \\
(58 \%)\end{array}$ & $60(100 \%)$ & 0 & 0 \\
\hline & & C & 0 & $1(20 \%)$ & $4(80 \%)$ & $5(100 \%)$ & 0 & 0 \\
\hline \multirow{3}{*}{\multicolumn{2}{|c|}{$\begin{array}{l}\text { Total and } \\
\text { percentage of } \\
\text { respondents } \\
\text { according to item }\end{array}$}} & S1 & $0(0 \%)$ & $4 \quad(3 \%)$ & $\begin{array}{c}111 \\
(97 \%)\end{array}$ & $\begin{array}{c}115 \\
(100 \%) \\
\end{array}$ & $0 \quad(0 \%)$ & $0(0 \%)$ \\
\hline & & S2 & $0 \quad(0 \%)$ & $4 \quad(3 \%)$ & $\begin{array}{c}111 \\
(97 \%)\end{array}$ & $\begin{array}{c}115 \\
(100 \%)\end{array}$ & $0 \quad(0 \%)$ & $0(0 \%)$ \\
\hline & & S3 & $\begin{array}{c}56 \\
(49 \%) \\
\end{array}$ & $8 \quad(7 \%)$ & $\begin{array}{c}51 \\
(44 \%)\end{array}$ & $\begin{array}{c}115 \\
(100 \%)\end{array}$ & $0 \quad(0 \%)$ & $0(0 \%)$ \\
\hline \multicolumn{2}{|c|}{$\begin{array}{l}\text { Overall percentage } \\
\text { to S - Satisfaction } \\
\text { element }\end{array}$} & $\frac{S 1+S 2+S 3}{3 \times 115}$ & $16.2 \%$ & $4.6 \%$ & $79.2 \%$ & $100 \%$ & $0 \%$ & $0 \%$ \\
\hline
\end{tabular}

Based on Table 4.0, all 115 respondents responded to both the Pre and Post segments of IPPK usage. In general, the overall percentage for the Compatibility in the Post segment clearly sided $100 \%$ to the choosing of Agree only. However, in the pre-segment, there was a mixture between Agree (16.2\%) Disagree (4.6\%), and Unsure (79.2\%). Referring to the total 
and percentage of respondents according to item, the Post segment for S1, S2, and S3, $100 \%$ of the respondents chose Agree while none of the respondents (0\%) chose Disagree of Unsure. However, a difference can be seen in the pre-segment whereby for S1, Agree $(0 \%)$, Disagree (3\%), and Unsure (97\%). For item S2 in the pre-segment, Agree (0\%), Disagree (3\%), ad Unsure (97\%). For item S3 in the pre-segment, Agree (49\%), Disagree (7\%), and Unsure (44\%).

Referring to item S1, all 115 respondents each gave responses for the Pre and Post usage of IPPK. For the Post segment, all 115 (100\%) of respondents from all three samples agreed that they are able to use the IPPK model to measure future success. Therefore, the findings for Disagree and Unsure in the Post segment is recorded at $0 \%$ each. This is a positive development when compared to the pre-segment as no respondents $(0 \%)$ whom agreed has an early notion that they could use the IPPK model to measure future success. As many as three respondents from Sample A chose Disagree whereas the remaining 47 respondents chose Unsure. One respondent from Sample $C$ chose Disagree and the other four chose Unsure. All 60 respondents from Sample B chose Unsure. This shows that IPPK creates natural causes, therefore gives encouragement to reflect on the weaknesses of the self.

Referring to item S2, all 115 respondents each gave responses for the Pre and Post usage of IPPK. For the Post segment, all 115 (100\%) of respondents from all three samples agreed that the IPPK model spurred their motives to move towards success. Therefore, the findings for Disagree and Unsure in the Post segment is recorded at $0 \%$ each. This is a positive development when compared to the pre-segment as there were no respondents $(0 \%)$ whom agreed that they had an early notion that the IPPK model could spur their motives to move towards success. Two respondents from Sample A chose Disagree while the remaining 48 respondents chose Unsure. 2 respondents from Sample $C$ chose disagree and the other two chose Unsure. All 60 respondents from Sample B chose Unsure. Overall, the motivation for $100 \%$ of the respondents comes from the Post segment as compared to $0 \%$ of the presegment. This shows that IPPK creates positive causes, therefore encouraging students to move in line with the motives formed.

Referring to item S3, all 115 respondents each responded for Pre and Post IPPK usage. For the Post segment, all 115 (100\%) of respondents from all three samples agreed that the IPPK model triggered they positive self-worth such as doing practice drills. Therefore, the findings for Disagree and Unsure in the Post segment stands at $0 \%$. However, there are 31 respondents from Sample A and 25 respondents from Sample B had already predicted that IPPK was of a positive trigger for self. As many as seven respondents from Sample A chose Disagree while 12 other respondents chose Unsure. One respondent from Sample $C$ chose Disagree while the remaining four respondents chose Unsure. As many as 35 respondents from Sample B chose Unsure. Overall, the agreement between the students towards the capabilities of the IPPK model to trigger positive self-worth increased from $48.7 \%$ in the presegment to $100 \%$ in the Post segment. This goes to show that IPPK creates equity whereby every respondent may determine their own targets according to their own capabilities.

As a whole, Keller's queries on the way to simplify the usage of new knowledge though meaningful chances are answered in the Post segment of item S1. Keller defined strategies to generate satisfaction as the effort to strengthen achievements with rewards whether intrinsically or extrinsically. Through IPKK, the experience of a 'slow learner' student whom finally succeeds in overcoming a tough assignment can be the most gratifying experience. Other than that, the usage of skills or new knowledge such as language system clones or development measurement processes may increase the student's intrinsic motivation to gain 
extrinsic rewards. IPPK encourages learning activities based on experiences which then becomes high effective tools. Referring to S2: Positive causes, students given the freedom to perform reinforcement activities for future success. With the chance to see the learning potentials, especially though traffic colours, a student's emotions may be controlled when facing learning situations. In relation to S3: Equity, in line with Keller's thoughts, IPPK assists students to create positive feelings on achievements in learning. According to Keller, a third person's achievements influences the feelings of the a student. Due to the tendency to make comparison, a student will easily feel happiness if they are able to surpass other people, or feel disappointed if they are passed by other people. Therefore, IPKK would help to handle this equity problem by ensuring the results of the assignments are in line with the standards set.

\section{Conclusion}

Through this research, the ACRS Model of Motivation was found to be successful in influencing intrinsic motivational encouragement for all 115 respondents. The method of applying IPPK was easy and interesting, causing a continuity in activities such as selfreflection, self-adaptation, self-confidence, and finding self-satisfaction (Andrale, 2009). This extracted the desire to learn, to provide knowledge according to age suitability, form selfconfidence, and generate the student's self-satisfaction. Through the element of Attention, all respondents had their interests piqued to comprehend achievement in every language system clone. They were also stimulated to identify the strengths and weaknesses in the Malay Language comprehension paper. The respondents pictured IPPK as a tool that helps them to realise to be careful with weak language system clones. Through the element of Relevance, all respondents agreed on the three statement on the IPPK model. They responded that the IPPK model was suitable with levels of comprehension and age, giving a choice to arrange the next step, and that the user guide is clear and simple. From a Confidence perspective, all respondents chose to agree that the IPPK model helped to determine achievement targets in the next examinations. Other than that, they agreed that accept this model as a motivational tool to support progress and to help to understand true success. From a Relevance perspective, all respondents stated that IPPK may be used to measure future success. Other than that, the IPPK model may dig up motivation to improve on performance and trigger positive self-worth such as doing practice drills. This clearly indicated that IPPK is influential in creating self-satisfaction in the users. Based on these findings as a whole, it can be stated that IPPK is user-friendly, therefore able to problem-solve in easy and interesting ways. With this, IPPK clients can be acclimatized to look for alternative routes in facing future challenges. IPPK is also dynamic, whereby it may be adapted to suit the Classroom Assessment or Pentaksiran Bilik Darjah (PBD) trends. This means that the clients' motivation may be ensured to be always under control as it is accustomed to appreciating the self's potential rather than looking at the potential of others. This self-worth is able to reach the goals of the National Educational Philosophy to create a community with potential and balanced in terms of physical, emotional, spiritual, and intellectual, as well as have the ability to reach self-wellbeing (Chithra a/p Raju, 2003). This emotional balance encourages people to always use Malay Language as the main communication tool in everyday life. Therefore, the ARCS Model of Motivation and the IPPK Model complement the agenda to extract developmental motivation in mastering the national language among students who are nonnative speakers. As a whole, motivation plays a massive role in determining the level of selfcontrol or motivation through achievement, as mentioned by (Azizi et al., 2005). 


\section{Acknowledgement}

The highest appreciation goes to the Ministry of Education, Malaysia especially Director of Education of Policy Planning and Research Division, the Director of Negeri Sembilan State and Selangor State Education Departments, the head masters of National Type Tamil Primary Schools (SJKT) Cairo-Mantin, Ladang Semenyih, Ladang Rinching and Ladang Dominion in Hulu Langat District, Selangor upon permission granted to conduct this research. The permission and cooperation given by National Library of Malaysia in Kuala Lumpur, Sultan Abdul Samad Library in Putra University of Malaysia, Tun Seri Lanang Library in National University of Malaysia and Malaysian Teacher Education Institute, Raja Melewar Campus library in Seremban to conduct literature review is also highly commended.

\section{Corresponding Author}

Prof. Vijayaletchumy Subaramaniam

Phd from Department of Malay, Faculty of Communication and Modern Languages, Putra University of Malaysia, Serdang, the state of Selangor, Malaysia.

Email: vletchumy@upm.edu.my.

\section{References}

Andrade, H. (2009) Promoting Learning and Achievement through Self-Assessment. University of Albany, New York. Accessed on 2.11.2019 through scholarsarchieve.library. albany.edu/cgi/view content.cgi?=1011\&context_etap _far_scholar.

Bakar, Z. A., \& Haridas, S. H. (2015). Academic achievement in national type Tamil schools with the status of schools with fewer students (SKM) in the district of Kota Tinggi, Johore. Retrieved from eprints.utm.my.

Chithra, R. (2003). Attitudes and motivations of Indian students in learning Malay as a second language. Project paper Master of Education. Faculty of Education, Universiti Kebangsaan Malaysia.

Cook, V. (1991). Second language learning and language teaching. London: Edward Arnold.

Daily School Management Division of Ministry of Education, Malaysia Daily School

Management Section, Ministry of Education, Malaysia. (2018). 2018 Yearly Postmortem Report. Retrieved form https://www.moe.

Elliot, J. (1993). Professional Education and the Idea of a Practical Education Science. In Reconstructing Teacher Education. London: The Falmer Press.

Husaini, N. E., \& Salleh, C. I. (2017) Malay Grammar Errors in Second Language Learning, MAHAWANGSA 4(2), 273-284, Retrieved from http://www.mahawangsa. upm. edu.my

Ismail, A., \& Zakaria, N.(2019) Factors Influencing Malay Language Learning Motivation Among Students at SJKC Chung Hwa Teluk Kemang. International Journal of the Malay World and Civilisation 7(3), 23-30. Retrieved from http://journalarticle. ukm.my/13514/1/jatma-2019-0703-03.pdf.

Ismail, W. R. W. (2020). Failure Is Not End of Life. Pelita Bahasa, 7, 11-13. DBP: Kuala Lumpur.

Keller, J. M. (2010). Motivational Design for Learning and Performance The ARCS Model Approach. New York, Amerika : Springer.

Mahmud, W. M. R. (2012). The stress of facing exams. Retrieved from jpnperak. moe.gov. $\mathrm{my} / \mathrm{jpn}$. 
Mahmudah, S. (2016) ARCS Model in English as a Foreign Language Class (A Descriptive Study in the Eleventh Grade of MA NU Salafiyah Demak in the 2015/2016 Academic Year). Final project submitted to obtain Bachelor Degree in Education (English Language Education). Walingso State Islamic University, Semarang, Indonesia. Retrieved from http://eprints.walisongo.ac.id/6062/1/ 113411012.pdf

Metro Daily (Harian Metro), Malaysia 30.4.2019

Ooi, C. H., \& Subramanian, V. (2016) Pupils' Motivation Level in Learning Malay as a Second Language. Retrieved from Ulum Islamiyyah Journal VOL.18 (DECEMBER) 2016 : pp 115-130.

Nathesan, S. (2012). Malay Easy to Learn but Difficult to Master? Pelita Bahasa, 8-11, DBP: Kuala Lumpur.

Peng, C. F. (2016). Malay language learning problems among primary school Chinese students. Malay Language Education Journal, 6(2), 10-22.

Pormalu, S., Kamaruddin, R., Muthusamy, P., Bakari, A. M., \& Mansor, H. H. (2017). Learning Malay as a Second Language among Tamil School Students. International Journal of the Malay World and Civilisation (Iman) 5(1), 45-55 (http://dx.doi.org/10.17576/IMAN-2017-0501-05)

Razin, A. S. A., \& Subramaniam, V. (2019) Misuse of Prefixes and Suffixes among National Type Tamil School Pupils Based on Corder Error Analysis Theory (1973). Retrieved from International Journal of the Malay World and Civilisation 7(1), 3-13 (https:doi.org/10.17576/jatma-2019-0701-01).

Yahya, A., Boon, Y., \& Noordin, K. (2005). The Relationship between Self-Concept, Motivation and Parenting style With Student Achievement. Retrieved from http://eprints.utm.my/id/eprint/2332/2/AziziYahay_Hubungan_Konsep_Kendiri \%2C motivasi_dan_gaya.pdf. 